\title{
MAPPING THE VEGETATION OF MOLHAȘUL MARE FROM IZBUC PEAT BOG, APUSENI MOUNTAINS (ROMANIA)
}

\author{
Gheorghe COLDEA, Tudor Mihai URSU, Emanoil PLAMAD $\breve{A}$ \\ National Institute of Research and Development for Biological Sciences, Institute of Biological Research Cluj, \\ 48 Republicii str., RO-400015 Cluj-Napoca, Romania \\ e-mail: tudor.ursu@icbcluj.ro
}

\begin{abstract}
This paper presents, on the basis of floristic and phytocoenotic data from field studies and the literature, the real vegetation map of Molhaşul Mare from Izbuc peat bog, in the Apuseni Muntains. This oligotrophic bog, situated at $46^{\circ} 35^{\prime} 29^{\prime \prime} \mathrm{N}$ and $22^{\circ} 45^{\prime} 43^{\prime \prime} \mathrm{E}$, is the most representative from this area and the least impacted by human activities, being therefore declared a Botanical Reserve. On its surface of $c .8$ ha, there have been identified, described on floristic and ecological grounds and mapped at 1:1000 scale, 9 plant community types that correspond to 4 Natura 2000 habitat types: $7110^{*}, 7149,7150$ and 91D0*. The vegetation map will be useful for monitoring the conservation status of the plant communities and habitats and will facilitate the establishment of suitable conservation measures for the protection of the peat bog.
\end{abstract}

Key words: vegetation map, peat bog, oligotrophic, Apuseni Mountains

\section{Introduction}

The peat bogs of Romania have been comprehensively studied by Academician Emil Pop, from the topographical, floristic and palynological points of view, for more than three decades, between 1929 and 1960.

The results of this research were published in the monographic work "The Peat Bogs of Romania" [12]. The mainly oligotrophic peat bogs, numbering 265, have a total surface of c. 1350 ha and, together with the 170 eutrophic peat bogs, comprise a total area of 5730 ha [12], representing only $0.025 \%$ of the area of Romania. Nevertheless, the ecological conditions of these vegetation types allow the survival of rare plant species, such as Carex loliacea, $C$. chordorrhiza, Calla pallustris, Stellaria longifolia, Saxifraga hirculus, Pedicularis sceptrumcarolinum, Achillea impatiens, Betula nana, B. humilis, Salix bicolor, S. myrtilloides, Ledum palustre and Viola epipsila, that have their south-eastern limit in the Romanian Carpathians. Also, they host some rare bryophyte species such as Paludella squarrosa, Meesia longiseta, M. hexasticha and Sphagnum wulfianum. Along with these, other species typical for oligotrophic bogs occur, such as Andromeda polifolia, Scheuchzeria palustris, Vaccinium oxycoccos, $V$. microcarpum, Carex limosa, C. magellanica, C. pauciflora, Eriophorum gracile and E. vaginatum that extend beyond the southern border of Romania. These plant taxa are specific to priority habitat $7110^{*}$ Active raised bogs, which, in the territory of Romania, are best represented in the area of the Eastern Carpathians and to a lesser extent in the Apuseni Mountains. From the latter area, the most representative active raised bog based on floristic and phytocoenological considerations is Molhașul Mare from Izbuc peat bog, which was designated a Botanical Reserve in 1982. In 2000 it was declared a protected area (IUCN category IV) while today it is also 
included within the Apuseni Natural Park and the Natura 2000 sites ROSCI0002 and ROSPA0081.

This article aims to reveal the following structural and functional characteristics of this peat bog: i) highlighting the floristic and phytocoenological diversity; ii) large-scale mapping (1:1000) of the plant communities, aiming to help the monitoring of their dynamics; iii) management measures necessary for the conservation of the floristic-ecological structure of the bog.

\section{The study area}

Mohașul Mare from Izbuc is situated in the source region of the Izbuc Valley, a headwater branch of the Someşul Cald river, originating at the foot of the karstic plateau Tămaşca-Ponor, at its contact with Bătrâna Mountain. The peat bog lies on the right terrace of the Izbuc Valley, spanning some 8 ha and having an oval central part, without trees, while its edges (on its eastern, southern and western sides) are transitioning into a bog woodland with spruce (Picea abies). In the wooded edges, the peat layer depth varies between 50 and $150 \mathrm{~cm}$, whereas in the centre area, which is visibly raised in the middle, the maximum thickness of the peat is $565 \mathrm{~cm}[3,10]$ or $620 \mathrm{~cm}$ [9]. The geological substrate of the bog area is made up of Permian sandstone. The published sporo-pollen diagrams [3, 9] reveal that the bog formation began with the accumulation of excess spring water, in the warm and moist Atlantic period. The first forest phase identified between the levels $620-650 \mathrm{~cm}$ of the profile is the phase of spruce with mixed oak, followed in the Subboreal $(560-460 \mathrm{~cm})$ by the phase of spruce with hornbeam where the spores of Sphagnum have a high frequency (63\%). Next comes the long Subatlantic period (460$10 \mathrm{~cm}$ ) characterized by a specific climate, moist and cold, typical for the beech (Fagus sylvatica) phase. The Sphagnum spores reach their maximum frequency in this period, 118\% [9], proving that the increasing oceanic character of the climate created optimum conditions for the development of Sphagnum species and the increase of the peat deposit within the bog. The palynological analyses show that most of the peat layer from this site was formed within the beech phase [3,9]. Currently, the central part of the bog, situated at $46^{\circ} 35^{\prime} 29^{\prime \prime} \mathrm{N}$ and $22^{\circ}$ 45'43' E, covers 2.3 ha, is without trees and has 8 small bog-pools (Blänken) and 13 small waterfilled hollows (Schlenken), as well as several hummocks (Bülten), where different plant communities or species occur.

\section{Material and Methods}

Although some floristic data regarding the bog had already been published in the middle of the last century [11], phytocoenotic research started much later [5, 4, 13] and continued intermittently until 1998, when the large-scale mapping (1:1000) of the 9 plant communities identified within the bog was completed. The phytocoenological relevés were carried out according to the classical Central-European method [1]. The relevé surface varied between 2-4

$\mathrm{m}^{2}$ for the herbaceous communities and 150-200 $\mathrm{m}^{2}$ for the bog woodland that surrounds the central part. For the field mapping of the real vegetation [6], the study area was divided by using a measuring roulette into $10 \mathrm{~m} / 10 \mathrm{~m}$ squares marked by stakes. One or more relevés were recorded in each such grid cell, according to vegetation diversity. The contours of the plant communities from each grid cell were transposed on to millimeter paper resulting in the paper map of the peat bog vegetation. Subsequently, in order to import the data into GIS software [8], the paper map was scanned and the obtained image was georeferenced in the Stereo 1970 
projection system using the aerial imagery of the peat bog. Consequently, the boundaries of the plant communities from the scanned image were digitized into polygons that allowed generation of the digital version of the map.

\section{Results and Discussions}

\section{Floristic particularities}

The soil and ecological conditions are variable both in the marginal bog woodland where the layer of peat is thinner, under $1 \mathrm{~m}$, and the plant roots can still access some minerals from the ground, and in the central part with much thicker peat $(2-6 \mathrm{~m})$, where the oligotrophic plants acquire the nutrients solely from rainwater. These diverse conditions had the most important contribution in the natural selection and distribution of plant species throughout the bog. Out of the 82 cormophyte species identified within whole surface of the bog, only 10 grow in the central area. These oligotrophic species are Andromeda polifolia, Drosera rotundifolia, Vaccinium microcarpum, Carex limosa, C. pauciflora, Empetrum nigrum, Pedicularis limnogena, Valeriana simplicifolia, Rhynchospora alba and Scheuchzeria palustris. Their phytogeographical specificity and limited distribution within the Apuseni Mountains confer the peat bog a major phytohistorical significance. It is important to mention that currently this is the only known location in the Apuseni Mountains for the sedge Rhynchospora alba. Until 1989 this species was also present in Molhaşul from Călăţele peat bog but after 1995 this bog was completely destroyed for peat extraction. The remaining 72 cormophyte species grow within the surrounding bog woodland and only a few are present both in the central and marginal area, such as Eriophorum vaginatum, E. angustifolium, Carex echinata, C. curta, C. rostrata, Calluna vulgaris, Molinia caerulea, Agrostis canina, Epilobium palustre, Potentilla erecta, Caltha palustris, Myosotis scorpioides, Galium uliginosum, Vaccinium myrtillus and V. vitis-idaea. From the plant species typical of spruce forests present only in the marginal area, the more important are: Athyrium filix-femina, Dryoptheris carthusiana, Deschampsia flexuosa, Melampyrum sylvaticum, Homogyne alpina, Soldanella oreodoxa, Luzula sylvatica, Lycopodium clavatum, L. annotinum, Huperzia selago, Carex brizoides, Listera cordata, Calamagrostis arundinacea, Salix cinerea, Leucanthemum rotundifolium, Filipendula ulmaria and Sorbus aucuparia. The typical oligotrophic species reveal the ombrogenous character of the bog, while its regional traits are indicated by species such as Leucanthemum rotundifolium, Soldanella oreodoxa, Valeriana simplicifolia and Pedicularis limnogena. From the bryophyte species with major role in building and differentiating the specific plant communities, we mention Sphagnum fuscum, S. magellanicum, S. cuspidatum, S. recurvum agg., S. russowii, Cladopodiella fluitans, Polytrichum strictum, P. commune, Calliergon stramineum. Sphagnum fuscum is dominant over $S$. magellanicum (c. $75 \%-25 \%$ of surface cover), attesting to the bog's continental character.

\section{Vegetation characterization}

The 178 relevés carried out within the peat bog were grouped, based on floristicecological characteristics, into 9 syntaxa, assembled into the following coenosystem:

Cls. OXYCOCCO-SPHAGNETEA Br.-B1. et Tx. 1943

Ord. SPHAGNETALIA MAGELLANICI Kästner et Flössner 1933

Al. Sphagnion magellanici Kästner et Flössner 1933

1. Ass. Sphagnetum magellanici (Malcuit 1929) Kästner et Flössner 1933 
2. Ass. Empetro nigri-Sphagnetum fusci Osvald 1923

3. Ass. Eryophoro vaginati-Sphagnetum recurvi Hueck 1925

CIs. SCHEUCHZERIO-CARICETEA FUSCAE (Nordh. 1936) Tx. 1937 Ord. SCHEUCHZERETALIA PALUSTRIS Nordh. 1936

Al. Rhynchosporion albae W. Koch 1926

4. Ass. Caricetum limosae Br.-B1. 1921

5. Ass. Rhynchosporetum albae (Osv. 1923) Koch 1926

Ord. CARICETALIA FUSCAE W. Koch 1926 em. Nordh. 1936

Al. Caricion fuscae W. Koch $1926 \mathrm{em}$. Klika 1934

7. Ass. Carici rostratae-Sphagnetum Steffen 1931

6. Ass. Carici echinatae-Sphagnetum Soó 1954

Cls. VACCINIO-PICEETEA Br.-B1. 1939

Ord. PICEETALIA Pawl. in Pawl. et al. 1928

Al. Betulion pubescentis Lohm. et Tx. 1955

8. Ass. Sphagno magellanici-Pinetum mugo Hadač et al. 1969

9. Ass. Sphagno magellanici-Piceetum Zukrigl. 1973

These 9 associations (Fig. 1) correspond to 4 types of Natura 2000 habitats [7]: 7110* Active raised bogs (community types 1, 2 and 3), 7150 Depressions on peat substrates of the Rhynchosporion (4 and 5), 7140 Transition mires and quacking bogs (6 and 7), and 91D0* Bog woodland (8 and 9). Next, the floristic, soil and ecological features of each plant community type and the placement of the communities throughout the peat bog are presented. For each mapped plant community we present a typical vegetation relevé.

1. Ass. Sphagnetum magellanici (16 relevés were performed) - most of its coenoses are localized in the northern part of the bog but a few are also scattered towards the centre, in the raised areas with no stagnant water and where the peat layer is more than $3 \mathrm{~m}$ deep and strongly acidic ( $\mathrm{pH}: 4.1-4.4)$. The area occupied by these coenoses is very small, under $1 \%$ of the central part of the bog The important plant species for this community type are: Sphagnum magellanicum 4.5, S. fuscum 1.3, S. recurvum agg. +.2, S. russowii +.1, Carex pauciflora 2.3, Andromeda polifolia 1.3, Vaccinium microcarpum +.2 , Empetrum nigrum 1.1, Eriophorum vaginatum +.3 , Drosera rotundifolia +.1 , Vaccinium myrtillus 1.1, V. vitis-idaea +.2 , Picea abies +.1 , Polytrichum strictum 2.3 .

2. The plant communities that occupy most of the central part of the bog (c. $60 \%$ ) belong to Ass. Empetro nigri-Sphagnetum fusci (77 relevés). The typical plant species are: Sphagnum fuscum 4.5, S. magellanicum 1.2, S. recurvum agg. +2 , S. russowii +2 , Polytrichum strictum + 1, Empetrum nigrum 2.3, Andromeda polifolia 1.3, Vaccinium microcarpum +2 , Empetrum nigrum 1.1, Eriophorum vaginatum 1.1, Vaccinium myrtillus +, Molinia caerulea +, Melampyrum silvaticum + , Calluna vulgaris + , Sphagnum tenellum + , Calliergon stramineum.+ Some of the communities of this type that form on hummock areas (Bülten) are dominated by Calluna vulgaris and Molinia caerulea while those from flat, more humid areas are dominated by Andromeda polifolia, thus being distinguished local facies, well individualized physiognomically (Fig. 1). These communities resemble those from the Czech Republic [2] and Slovenia [14]. 


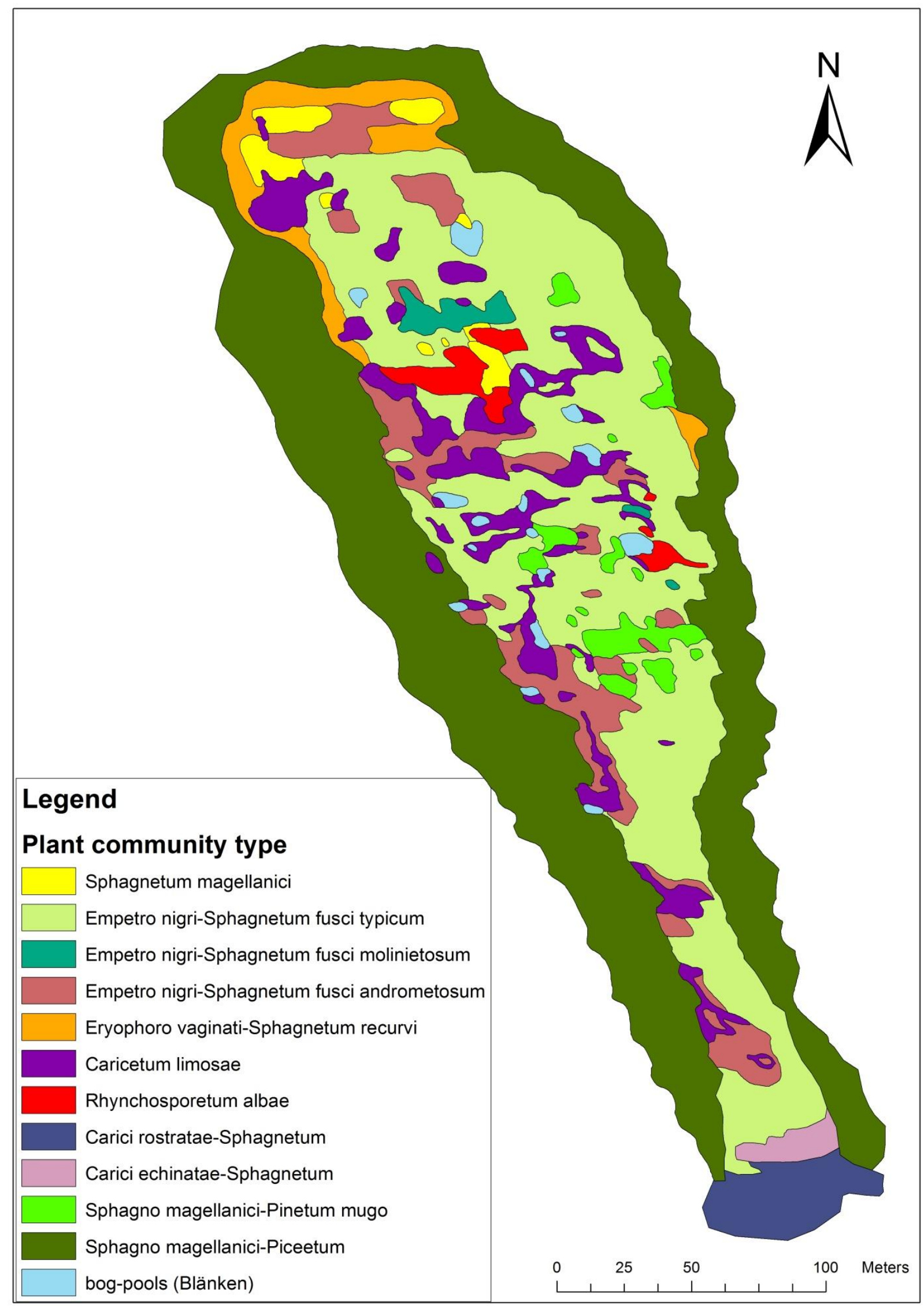

Fig. 1: Vegetation map of the Izbuc active peat bog 
3. Ass. Eriophoro vaginati-Sphagnetum recurvi (18 relevés) has a meso-oligotrophic character and occurs on compact areas only in the northern and north-eastern part of the bog, where it comes into contact with the bog woodland. The typical plant species of this community type are Sphagnum recurvum agg. 3.5, S. fuscum 1.1, S. magellanicum +1 , Carex pauciflora 2.4, Andromeda polifolia 1.2, Empetrum nigrum 1.3, Vaccinium microcarpum + , Drosera rotundifolia + , Calluna vulgaris + , Vaccinium myrtillus + .

These three types of communities are assembled into the Natura 2000 habitat $7110^{*}$ Active raised bogs. Within the area of this habitat there are a few small bog-pools (Blänken) and water-filled hollows (Schlenken) with very acidic water ( $\mathrm{pH} 4.05-4.20)$ and very low concentration of minerals that host the coenoses of Carex limosa and Rhynchospora alba [4].

4. The communities from Ass. Caricetum limosae (26 relevés) occur mainly on the edges of the bog pools and in the hollows where during summer the water level decreases significantly. The typical species are Carex limosa 4.5, Scheuchzeria palustris 1.2 and Sphagnum cuspidatum 2.4. Along the following oligotrophic species are also frequent: Drosera rotundifolia +.5 , Drepanocladus revolvens +.5 , Sphagnum magellanicum $+.3, S$. russowii +.3 and Gymnocolea inflata +.2 .

5. Ass. Rhynchosporetum albae (7 relevés) occurs in the central part of the bog, in a partially clogged area of a pool, in contact with the communities of Carex limosa. The dominant species for this community type are Rhynchospora alba 4.5 and Sphagnum cuspidatum 3.5, constantly accompanied by the oligotrophic species Drosera rotundifolia +.3 , Vaccinium microcarpum +.3 , Carex pauciflora +.3 , Scheuchzeria palustris +.2 and Carex limosa +.2 . It is important to mention once more that this is the only location for Rhynchospora alba in the Apuseni Mountains, the other previous location known (Molhaşul de la Călăţele peat bog) being completely destroyed through peat extraction before 1995 .

In the southern part of the bog, where the peat layer is thinner, under $1 \mathrm{~m}$, eumesotrophic, transition communities develop, dominated by the sedges Carex rostrata and Carex echinata.

6. The coenoses of Ass. Carici rostratae-Sphagnetum recurvi (7 relevés) are established in the south-western part of the bog, in areas with excessive moisture throughout the year. The dominant species are Carex rostrata 3.5, Sphagnum recurvum agg. 3.3, S. magellanicum 1.3 and Polytrichum commune 1.3. Along these, sporadically, appear also Carex echinata + , Carex curta +.3 , Eriophorum vaginatum +.2 , Deschampsia caespitosa +.2 , Juncus effuses +.3 , Filipendula ulmaria +. 2, Galium palustre +.1 , Caltha palustris +.2 , Vaccinium myrtillus + and $V$. vitis-idaea + .

7. Ass. Carici echinatae-Sphagnetum recurvi (5 relevés) is represented by coenoses that develop towards the edges of the central part, in raised areas where water is not pooling during the vegetation season. The dominant species in this case are Carex echinata 3.4, Carex curta 1.2, and Sphagnum recurvum agg. 4.5. Additionally are present, with sporadic occurrence, Carex nigra +.2 , Carex leporina +.2 , Juncus conglomeratus +.1 , Potentilla erecta 1.1, Pedicularis limnogena 1.1 and Polytrichum commune 1.2. In the eastern part of the bog, on the higher areas with reduced moisture, some bushes of mugo pine (Pinus mugo) occur.

8. Ass. Sphagno magellanici-Pinetum mugo ( 9 relevés) is characterized by the presence of Pinus mugo 4.5, Vaccinium myrtillus 2.3, V. vitis-idaea +.3, Empetrum nigrum +.3 , Melampyrum sylvaticum +.3 , Eriophorum vaginatum +.2 , Andromeda polifolia +.1 , Sphagnum 
magellanicum 1.2, S. fuscum +.1, S. capillifolium +.1 and Polytrichum strictum +.3.

9. The bog woodland, which belongs to Ass. Sphagno-Piceetum (13 relevés), surrounds the central bog area on all sides as a 20-25 m band, except for the northern side, bordered by the Izbuc Valley. The plant species assembling this community type are: Picea abies 4.5, Sorbus aucuparia 1.3, Lycopodium annotinum 1.2, L. clavatum +.1, Huperzia selago 1.3, Homogyne alpina + , Soldanella oreodoxa + , Eriophorum vaginatum 1.3, Vaccinium myrtillus 3.5, V. vitisidaea +.1 , Calamagrostis arundinacea + , Deschampsia flexuosa + , Listera cordata + , Carex pauciflora + , C. brizoides 1.2, Empetrum nigrum + , Equisetum sylvaticum + , E. telmateja + , Melampyrum sylvaticum + , Dryopteris carthusiana + , Oxallis acetosella 1.3, Luzula sylvatica + , Carex curta +, Veronica urticifolia +, Gymnocarpium dryopteris +.3 , Sphagnum russowii 3.5, Dicranum scoparium 1.3, Polytrichum commune 2.3, Plagiothecium undulatum 1.1, Bazzania trilobata +.2, Calypogeia neesiana + , Hylocomium splendens 1.3, Pleurozium schreberii 1.3, Sphagnum girgensohnii 1.1 and S. capillifolium 1.1 .

The most significant management measures required for the conservation of the bog are:

1. Preventing the felling of the spruce (Picea abies) forest surrounding the bog in order to avoid the drying of the site.

2. Preventing the building of access paths to the bog and on its surface.

3. Preventing the access and grazing of animals (particularly sheep) on the surface of the bog.

\section{Conclusions}

$\checkmark$ The Izbuc Active bog is the most representative for the Apuseni Mountains from floristic and ecological considerations (being protected as Nature Reserve) and has a favourable conservation status.

$\checkmark$ The sporo-pollen analyses have shown that this bog formation began in the Atlantic period, in the phase of spruce with mixed oak, continued through the Subboreal in the phase of spruce with hornbeam and completed in the Subatlantic, in the beech phase.

$\checkmark$ The plant species rare for Romania, with relict distribution areas, such as Scheuchzeria palustris, Carex limosa, Carex parviflora, Andromeda polifolia, Rhynchospora alba, Vaccinium microcarpum and Empetrum nigrum, growing throughout the raised bog, confer upon it an important floristic and scientific value.

$\checkmark$ The large-scale real vegetation map of the bog will facilitate the monitoring of plant species and communities and support the improvement of the conservation measures for this site.

Acknowledgements: We thank the anonymous reviewers for the useful suggestions that improved the manuscript. This work was partially supported by a grant from the Ministry of Research and Innovation through Program 1 - Development of the National R \& D System, Subprogram 1.2 - Institutional Performance - Projects for Excellence Financing in RDI, Contract no. 22PFE/2018. This study was also supported by the program BIODIVERS 2, Contract no. 30N/2018. We thank Dr. Liviu Filipaş for help with the first version of the vegetation map.

\section{REFERENCES}

1. Braun-Blanquet, J., 1964, Pflanzensoziologie, Grundzüge der Vegetationskunde. 3 ed. - Springer, Wien.

2. Chytrý, M., (ed.), 2011, Vegetation of the Czech Republic, 3. Aquatic and Wetland vegetation, Academia, Praha. 
3. Ciobanu, I. (1965): Analize de polen în turba unor mlaștini de pe cursul superior al Someşului Cald. Contrib.Bot., 5: 283-298.

4. Coldea, Gh., Markievici, F., 1978, Chemical composition of three raised peat bog waters from Romania, Rev. Roum. Biol. Ser. Biol. veget., 23 (1): 95-99.

5. Coldea, Gh., Plămadă, E., 1970, Contribuții la studiul clasei Scheuchzerio-Caricetea fuscae Nordh. 1936 din România, Hidrobiologia, 11: 105-116.

6. Cristea, V., Gafta, D., Pedrotti, F., 2004, Fitosociologie, Ed. Presa Universitară Clujeană, Cluj-Napoca.

7. Gafta, D., Mountford, J., 2008, Manual de interpretare a habitatelor Natura 2000 din România, Ministerul Mediului şi Dezvoltării Durabile, Cluj-Napoca, Ed. Risoprint.

8. Quantum GIS Development Team, 2018, QGIS Geographic Information System, Open Source Geospatial Foundation. http://qgis.osgeo.org.

9. Lupșa, V., 1983, Analiza sporo-polinică a turbei din Molhașul Mare de la Izbuc (Munții Bihorului), Ocrot. Nat. Med. Înconj, București, 27 (2): 118-121.

10. Mitroiescu, S., 1987, Analiza palinologică comparativă a turbei din tinovul "Molhașul Mare de la Izbuc", Munții Apuseni, Contrib. Bot., 27: 75-82.

11. Pop, E., 1939, Observații și date floristice III. Plante noi și rare din Munții Apuseni, Bul. Grăd. Bot. Cluj, 19 (1-4): 55-58.

12. Pop, E., 1960, Mlaștinile de turbă din Republica Populară Română, Ed. Acad. Române, București.

13. Pop, I., Hodișan, I., Cristea, V., 1987, La végétation de certain tourbières de la vallé Izbuc (Départament de Cluj), Contrib. Bot., 27: 113-120.

14. Valachovič , M., (ed.), 2001, Rastlinné spoločenstvá Slovenska, 3.Vegetácia mokradi, Academia VEDA, Bratislava.

\section{CARTAREA VEGETAȚIEI DIN MOLHAȘUL MARE DE LA IZBUC - MUNȚII APUSENI (ROMÂNIA)}

\section{(Rezumat)}

Lucrarea prezintă, pe baza datelor floristice şi fitocenotice proprii şi a celor existente în literatura de specialitate, harta de vegetaţie actuală a Molhaşuluil Mare de la Izbuc- M-ţii Apuseni. Acest tinov oligotrof, situat la 46 35'29” lat. N şi $22^{\circ} 45^{\prime} 43^{\prime}$ " long E, este cel mai reprezentativ din zona Munţilor Apuseni şi cel mai puţin antropizat, motiv pentru care a fost declarat rezervaţie botanică. Pe suprafaţa sa, de cca. 8 ha, au fost identificate, descrise sub aspect floristico-ecologic şi cartate la scara 1:1000, 9 asociaţii vegetale care se încadrează în urmatoarele 4 tipuri de habitate Natura 2000 din România: 7110*, 7149, 7150 and 91D0*. Harta de vegetaţie întocmită va putea fi utilizată pentru monitorizarea stării de conservare a fitocenozelor şi habitatelor şi va facilita adoptarea unor măsuri adecvate pentru protecţia tinovului pe viitor. 